\title{
Front Matter: Volume 8830
}

, "Front Matter: Volume 8830," Proc. SPIE 8830, Organic Photovoltaics XIV, 883001 (18 October 2013); doi: 10.1117/12.2045839

SDIE Event: SPIE Organic Photonics + Electronics, 2013, San Diego, California, SPIE. United States 


\section{PROCEEDINGS OF SPIE}

\section{Organic Photovoltaics XIV}

Zakya H. Kafafi

Paul A. Lane

Editors

\section{7-29 August 2013}

San Diego, California, United States

Sponsored by

SPIE

Cosponsored by

EMD Millipore Corporation (d.b.a. EMD Chemicals) (United States)

Published by

SPIE 
The papers included in this volume were part of the technical conference cited on the cover and title page. Papers were selected and subject to review by the editors and conference program committee. Some conference presentations may not be available for publication. The papers published in these proceedings reflect the work and thoughts of the authors and are published herein as submitted. The publisher is not responsible for the validity of the information or for any outcomes resulting from reliance thereon.

Please use the following format to cite material from this book:

Author(s), "Title of Paper," in Organic Photovoltaics XIV, edited by Zakya H. Kafafi, Paul A. Lane, Proceedings of SPIE Vol. 8830 (SPIE, Bellingham, WA, 2013) Article CID Number.

ISSN: 0277-786X

ISBN: 9780819496805

Published by

SPIE

P.O. Box 10, Bellingham, Washington 98227-0010 USA

Telephone +1 3606763290 (Pacific Time) · Fax +1 3606471445

SPIE.org

Copyright (C) 2013, Society of Photo-Optical Instrumentation Engineers.

Copying of material in this book for internal or personal use, or for the internal or personal use of specific clients, beyond the fair use provisions granted by the U.S. Copyright Law is authorized by SPIE subject to payment of copying fees. The Transactional Reporting Service base fee for this volume is $\$ 18.00$ per article (or portion thereof), which should be paid directly to the Copyright Clearance Center (CCC), 222 Rosewood Drive, Danvers, MA 01923. Payment may also be made electronically through CCC Online at copyright.com. Other copying for republication, resale, advertising or promotion, or any form of systematic or multiple reproduction of any material in this book is prohibited except with permission in writing from the publisher. The CCC fee code is $0277-786 \mathrm{X} / 13 / \$ 18.00$.

Printed in the United States of America.

Publication of record for individual papers is online in the SPIE Digital Library.

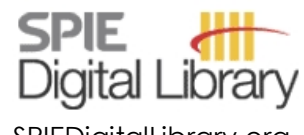

SPIEDigitalLibrary.org

Paper Numbering: Proceedings of SPIE follow an e-First publication model, with papers published first online and then in print and on CD-ROM. Papers are published as they are submitted and meet publication criteria. A unique, consistent, permanent citation identifier (CID) number is assigned to each article at the time of the first publication. Utilization of CIDs allows articles to be fully citable as soon as they are published online, and connects the same identifier to all online, print, and electronic versions of the publication. SPIE uses a six-digit CID article numbering system in which:

- The first four digits correspond to the SPIE volume number.

- The last two digits indicate publication order within the volume using a Base 36 numbering

system employing both numerals and letters. These two-number sets start with 00, 01, 02, 03, 04,

$05,06,07,08,09,0 A, 0 B \ldots$. OZ, followed by 10-1Z, 20-2Z, etc.

The CID Number appears on each page of the manuscript. The complete citation is used on the first page, and an abbreviated version on subsequent pages. Numbers in the index correspond to the last two digits of the six-digit CID Number. 


\section{Contents}

vii Conference Committee

NOVEL MATERIALS AND STRUCTURES FOR OPV ELECTRODES

883009 Efficiency enhancement in small molecular organic photovoltaic devices employing dual anode interfacial layers [8830-8]

T. Fleetham, B. O'Brien, Arizona State Univ. (United States); J. P. Mudrick, J. Xue, Univ. of Florida (United States); J. Li, Arizona State Univ. (United States)

TOWARDS EFFICIENT AND STABLE ORGANIC SOLAR CELLS: JOINT SESSION WITH CONFERENCES 8825 AND 8830

$8830 \mathrm{OE}$ Stability investigations of inverted organic solar cells with a sol-gel processed $\mathrm{ZnSrO}$ or ZnBaO electron extraction layer [8830-13]

O. Pachoumi, C. Li, Y. Vaynzof, K. K. Banger, H. Sirringhaus, Univ. of Cambridge (United Kingdom)

NOVEL APPROACHES AND ARCHITECTURES I

$88300 \mathrm{G}$ Towards high performance inverted polymer solar cells through interfacial reengineering (Invited Paper) [8830-15]

X. Gong, The Univ. of Akron (United States)

$8830 \mathrm{0l}$ Four-terminal organic solar cell modules with increased annual energy yield (Invited Paper) [8830-17]

R. Gehlhaar, D. Cheyns, L. Van Willigenburg, A. Hadipour, IMEC (Belgium); J. Gilot, Holst Ctr. (Netherlands); R. Radbeh, Solvay, MDA (Belgium); T. Aernouts, IMEC (Belgium)

$8830 \mathrm{OL}$ New insights into charge extraction and formation of the band-bending region in Schottky junction organic solar cells [8830-20]

S. Sutty, G. Williams, H. Aziz, Univ. of Waterloo (Canada)

NOVEL APPROACHES AND ARCHITECTURES II

8830 OP Patternable conjugated polymers for organic solar cells [8830-24]

P. Strohriegl, P. Knaver, C. Saller, E. Scheler, Univ. Bayreuth (Germany) 
8830 OU Improving the performance of P3HT/PCBM solar cells with squaraine dye [8830-29] J.-S. Huang, T. Goh, X. Li, Yale Univ. (United States); M. Y. Sfeir, Brookhaven National Lab. (United States); E. A. Bielinski, S. Tomasulo, M. L. Lee, N. Hazari, A. D. Taylor, Yale Univ. (United States)

\section{CHARGE GENERATION, TRANSPORT, AND RECOMBINATION IN OPVS}

883011 Empirically based device modeling of bulk heterojunction organic photovoltaics [8830-36] A. Pierre, Univ. of California, Berkeley (United States); S. Lu, Polyera Corp. (United States); I. A. Howard, Max Planck Institute for Polymer Research (Germany); A. Facchetti, Polyera Corp. (United States); A. C. Arias, Univ. of California, Berkeley (United States)

\section{STRUCTURAL PROBES OF THE OPV BULK HETEROJUNCTION}

883012 Morphology study on ternary blend polymer solar cell to achieve improved device performance (Invited Paper) [8830-37]

Y. Gu, Univ. of Massachusetts Amherst (United States); C. Wang, Lawrence Berkeley National Lab. (United States); F. Liu, Univ. of Massachusetts Amherst (United States); J. Chen, Oak Ridge National Lab. (United States); T. P. Russell, Univ. of Massachusetts Amherst (United States)

\section{DEVELOPMENT OF NEW POLYMERS FOR ORGANIC PHOTOVOLTAICS}

883019 Tailor-made absorber polymers for OPV: from synthesis to formulation development (Invited Paper) [8830-44]

S. Janietz, E. Katholing, A. Lange, Fraunhofer-Institut für Angewandte Polymerforschung (Germany); W. Schindler, Helmholtz-Zenzrum Berlin für Materialien und Energie GmbH (Germany)

$88301 \mathrm{~A}$ lonic high-performance light harvesting and carrier transporting OPV materials [8830-45] W. Maes, T. Ghoos, J. Kesters, Univ. Hasselt (Belgium) and IMEC (Belgium); J. Drijkoningen, IMEC (Belgium) and Univ. Hasselt (Belgium); W. Vanormelingen, Univ. Hasselt (Belgium) and IMEC (Belgium); O. Malinkiewicz, H. J. Bolink, Univ. de Valencia (Spain); L. Lutsen, Univ. Hasselt (Belgium) and IMEC (Belgium); J. Manca, Univ. Hasselt (Belgium); D. Vanderzande, Univ. Hasselt (Belgium) and IMEC (Belgium)

\section{POSTER SESSION}

$8830 \mathrm{lK}$ An optimization algorithm for designing robust and simple antireflection films for organic photovoltaic cells [8830-58]

S. Kubota, K. Kanomata, K. Momiyama, T. Suzuki, F. Hirose, Yamagata Univ. (Japan)

883010 Analysis of the thickness dependent photocurrent spectra of organic bulk heterojunction solar cells [8830-63]

B. K. Abeyweera, B. W. Alphenaar, Univ. of Louisville (United States) 
$88301 Q \quad$ High performance PEDOT:PSS films prepared through a treatment with fluoro compounds and their application in polymer solar cells [8830-65]

P. Kumar, A. Kumar, K. Santhakumar, Aichi Institute of Technology (Japan); P.-K. Shin, Inha Univ. (Korea, Republic of); S. Ochiai, Aichi Institute of Technology (Japan)

8830 1R Fabrication and characterizations of PBDTTPD: PC 71 BM bulk heterojunction solar cell using air brush coating method [8830-66]

P. Kumar, K. Santhakumar, J. Tatsugi, Aichi Institute of Technology (Japan); P.-K. Shin, Inha Univ. (Korea, Republic of); S. Ochiai, Aichi Institute of Technology (Japan)

8830 is Numerical modeling of time-resolved photocurrent in organic semiconductor films [8830-67]

B. Johnson, K. Paudel, M. J. Kendrick, O. Ostroverkhova, Oregon State Univ. (United States)

8830 1T Transparent bifacial dye-sensitized solar cells based on organic counter electrodes and iodine-free electrolyte [8830-68]

Z. Ku, Y. Rong, H. Han, Huazhong Univ. of Science and Technology (China)

$88301 \mathrm{~V}$ Insights into electron and hole extraction layers for upright and inverted vacuumdeposited small molecule organic solar cells [8830-70]

G. Williams, H. Aziz, Univ. of Waterloo (Canada)

$88301 \mathrm{~W} \quad$ Monolithic all-solid-state dye-sensitized solar cells [8830-71]

Y. Rong, Z. Ku, M. Xu, G. Liu, H. Wang, H. Han, Huazhong Univ. of Science and Technology (China)

8830 1Y Multiscale analysis of effect of solvents on the P3HT-PCBM active layer [8830-73] M. Huang, M. Liu, Tongji Univ. (China)

$883021 \quad$ Flexible PCPDTBT:PCBM solar cells with integrated grating structures [8830-76] R. M. de Oliveira Hansen, Y. Liu, M. Madsen, H.-G. Rubahn, Univ. of Southern Denmark (Denmark)

$88302 \mathrm{~F} \quad$ Third row metal complexes as an alternative dye in dye sensitized solar cell system [8830-90]

S. Wahyuningsih, A. H. Ramelan, I. Badriyah, I. O. Kristy, N. S. Dewi, S. B. Rahardjo, Sebelas Maret Univ. (Indonesia)

$88302 \mathrm{~L} \quad$ Ring-protected small molecules for organic photovoltaics [8830-96]

J. Sun, L. Zhang, A. Dubey, S. Venkatesan, South Dakota State Univ. (United States); T.-Y. Lin, National Tsing Hua Univ. (Taiwan); L. Sanow, South Dakota State Univ. (United States); Y.-C. Hung, National Tsing Hua Univ. (Taiwan); A. Sykes, Univ. of South Dakota (United States); H. He, Eastern Illinois Univ. (United States); Q. Qiao, C. Zhang, South Dakota State Univ. (United States)

Author Index 
Proc. of SPIE Vol. $8830883001-6$

Downloaded From: https://www.spiedigitallibrary.org/conference-proceedings-of-spie on 26 Apr 2023 Terms of Use: https://www.spiedigitallibrary.org/terms-of-use 


\title{
Conference Committee
}

\author{
Symposium Chair
}

Zakya H. Kafafi, National Science Foundation (United States)

Conference Chair

Zakya H. Kafafi, National Science Foundation (United States)

Conference Cochairs

Christoph J. Brabec, Friedrich-Alexander-Universität Erlangen-Nürnberg (Germany)

Paul A. Lane, U.S. Naval Research Laboratory (United States)

\section{Conference Program Committee}

Paul L. Burn, The University of Queensland (Australia)

René A. J. Janssen, Technische Universiteit Eindhoven (Netherlands)

Bernard Kippelen, Georgia Institute of Technology (United States)

Ana Flávia Nogueira, Universidade Estadual de Campinas (Brazil)

Barry P. Rand, IMEC (Belgium)

Ifor D. W. Samuel, University of St. Andrews (United Kingdom)

Sean E. Shaheen, University of Colorado at Boulder (United States)

Jiangeng Xue, University of Florida (United States)

Yang Yang, University of California, Los Angeles (United States)

He Yan, Hong Kong University of Science and Technology (Hong Kong, China)

Teketel Yohannes, Addis Ababa University (Ethiopia)

Session Chairs

1 Solution Processed Molecules for Organic Solar Cells I

Zakya H. Kafafi, National Science Foundation (United States)

2 Novel Materials and Structures for OPV Electrodes

Russell J. Holmes, University of Minnesota, Twin Cities (United States)

3 Towards Efficient and Stable Organic Solar Cells: Joint Session with Conferences 8825 and 8830

Bernard Kippelen, Georgia Institute of Technology (United States)

4 Novel Approaches and Architectures I

Deirdre M. O'Carroll, Rutgers, The State University of New Jersey (United States) 
5 Novel Approaches and Architectures II

Ana F. Nogueira, Universidade Estadual de Campinas (Brazil)

6 Solution Processed Molecules for Organic Solar Cells II

Sean E. Shaheen, University of Colorado at Boulder (United States)

7 Charge Generation, Transport, and Recombination in OPVs

Ifor D. W. Samuel, University of St. Andrews (United Kingdom)

8 Structural Probes of the OPV Bulk Heterojunction

Dana C. Olson, National Renewable Energy Laboratory (United States)

9 Development of New Polymers for Organic Photovoltaics

Peter J. Skabara, University of Strathclyde (United Kingdom)

Poster Session

Paul L. Burn, The University of Queensland (Australia) 